\title{
Romancing the Past
}




\section{The New Historicism: Studies in Cultural Poetics Stephen Greenblatt, General Editor}

1. Holy Feast and Holy Fast: The Religious Significance of Food to Medieval Women, by Caroline Walker Bynum

2. The Gold Standard and the Logic of Naturalism: American Literature at the Turn of the Century, by Walter Benn Michaels

3. Nationalism and Minor Literature: James Clarence Mangan and the Emergence of Irish Cultural Nationalism, by David Lloyd

4. Shakespearean Negotiations: The Circulation of Social Energy in Renaissance England, by Stephen Greenblatt

5. The Mirror of Herodotus: The Representation of the Other in the Writing of History, by François Hartog, translated by Janet Lloyd

6. Puzzling Shakespeare: Local Reading and Its Discontents, by Leah S. Marcus

7. The Rites of Knighthood: The Literature and Politics of Elizabethan Chivalry, by Richard C. McCoy

8. Literary Practice and Social Change in Britain, 1380-1530, edited by Lee Patterson

9. Trials of Authorship: Anterior Forms and Poetic Reconstruction from Wyatt to Shakespeare, by Jonathan Crewe

10. Rabelais's Carnival: Text, Context, Metatext, by Samuel Kinser

11. Behind the Scenes: Yeats, Horniman, and the Struggle for the Abbey Theatre, by Adrian Frazier

12. Literature, Politics, and Culture in Postwar Britain, by Alan Sinfield

13. Habits of Thought in the English Renaissance: Religion, Politics, and the Dominant Culture, by Debora Kuller Shuger

14. Domestic Individualism: Imagining Self in Nineteenth-Century America, by Gillian Brown

15. The Widening Gate: Bristol and the Atlantic Economy, 1450-1700, by David Harris Sacks

16. An Empire Nowhere: England, America, and Literature from "Utopia" to "The Tempest," by Jeffrey Knapp

17. Mexican Ballads, Chicano Poems: History and Influence in MexicanAmerican Social Poetics, by José E. Limón

18. The Eloquence of Color: Rhetoric and Painting in the French Classical Age, by Jacqueline Lichtenstein, translated by Emily McVarish

19. Arts of Power: Three Halls of State in Italy, 1300-1600, by Randolph Starn and Loren Partridge

20. Expositions: Literature and Architecture in Nineteenth-Century France, by Philippe Hamon, translated by Katia Sainson-Frank and Lisa Maguire

21. The Imaginary Puritan: Literature, Intellectual Labor, and the Origins of Personal Life, by Nancy Armstrong and Leonard Tennenhouse

22. Fifteen Jugglers, Five Believers: Literary Politics and the Poetics of American Social Movements, by T. V. Reed

23. Romancing the Past: The Rise of Vernacular Prose Historiography in Thirteenth-Century France, by Gabrielle M. Spiegel

24. Dearest Beloved: The Hawthornes and the Making of the Middle-Class Family, by T. Walter Herbert 


\section{A CENTENNIAL BOOK}

One hundred books

published between 1990 and 1995

bear this special imprint of

the University of California Press.

We have chosen each Centennial Book as an example of the Press's finest publishing and bookmaking traditions

as we celebrate the beginning of our second century. 


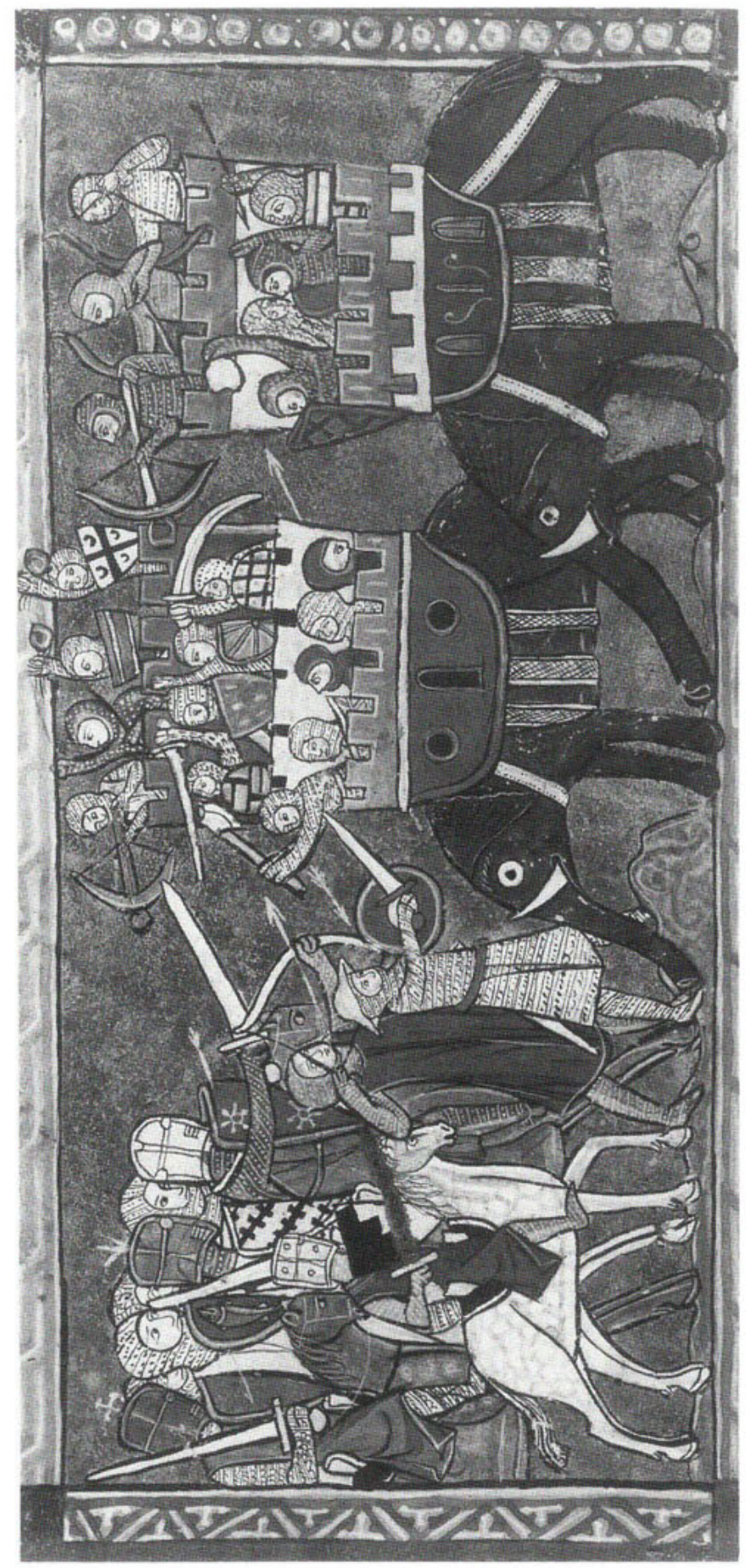

ปิ 


\section{Romancing the Past}

The Rise of Vernacular Prose

Historiography in

Thirteenth-Century France

GABRIELLE M. SPIEGEL

University of California Press

BERKELEY LOS ANGELES OXFORD 
The publisher gratefully acknowledges the contribution provided by the General Endowment Fund of the Associates of the University of California Press.

University of California Press

Berkeley and Los Angeles, California

University of California Press, Ltd.

Oxford, England

(C) 1993 by

The Regents of the University of California

Library of Congress Cataloging-in-Publication Data

Spiegel, Gabrielle M.

Romancing the past : the rise of vernacular prose historiography in thirteenth-century France / Gabrielle M. Spiegel.

p. $\quad \mathrm{cm}$. - (The New historicism ; 23)

"A Centennial book."

Includes bibliographical references and index.

ISBN 0-520-07710-5 (alk. paper)

1. French prose literature-To $1500-$ History and criticism.

2. France-History-Medieval period, 987-1515-Historiography.

3. French prose literature-Roman influences. 4. France-HistoryTo 987-Historiography. 5. Romances-History and criticism.

6. Literature and history. 7. Historiography-France. 8. RomeHistoriography. I. Title. II. Series.

PQ221.S66 1993

$848^{\prime} .10809-\mathrm{dc} 20$

Printed in the United States of America

$\begin{array}{lllllllll}9 & 8 & 7 & 6 & 5 & 4 & 3 & 2 & 1\end{array}$

The paper used in this publication meets the minimum requirements of American National Standard for Information Sciences-Permanence of Paper for Printed Library Materials, ANSI Z39.48-1984. (9) 
For Marcus and Alix

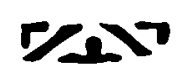

Because history is consummated only by being narrated, a critique of history may be practiced only as a narrative about how history, in narrating itself, is accomplished.

Jean-Pierre Faye, Théorie du récit 
